KALAM, P-ISSN: 0853-9510 E-ISSN: 2540-7759

http://ejournal.radenintan.ac.id/index.php/KALAM

Volume 10, No. 2, Desember 2016, halaman 491 - 516

\title{
Hubungan Antar Umat Beragama Dalam Perpektif Hadits
}

\author{
Salamah Noorhidayati \\ IAIN Tulung Agung, Jawa Timur \\ salamahnoorhidayati@gmail.com
}

\begin{abstract}
Abstrak
Dalam beberapa hal, Islam sering dituduh sebagai agama yang diskriminatif, khususnya terkait dengan relasi antar umat beragama. Tuduban ini didasarkan pada banyaknya hadis yang secara redaksional menunjukkan sikap yang demikian. Artikel ini mengelaborasi tipologi hadis-hadis tentang relasi umat beragama, konteks sosio-historis yang melatari kemunculannya dan model pembacaan yang konstruktif untuk konteks kekinian. Penelitian ini menemukan bahwa: Pertama, ada dua sikap hadis terbadap umat non muslim, yaitu apresiatif-akomodatif dan kritis-konfrontatif. Kedua, kedua kategori itu labir dalam konteks relasi sosial umat beragama yang dinamis-fluktuatif yaitu harmonis dan disharmonis. Ketiga, pembacaan yang konstruktif dilakukan dengan menggunakan pendekatan humanis-kontekstual.
\end{abstract}

\begin{abstract}
In some ways, Islam is often accused of being religious discrimination, particularly relating to inter-religious relations. This accusation is based on the many traditions that are semantically show that attitude. This article elaborates on the typology of traditions about the relation of religious, socio-bistorical context underlying the emergence and constructive reading model for the contemporary context. The study found that: First, there are two attitudes towards people of non-Muslim traditions, ie accommodating and appreciative-critical-confrontational. Second, the two categories was born in the context of socio-religious relations-volatile
\end{abstract}


dynamic that is harmonious and disharmonis. Third, constructive readings done by using contextual bumanist approach.

Key Words: Hadis, Diskriminatif, Toleransi.

\section{A. Pendahuluan}

Sebagai sebuah agama, Islam datang membawa seperangkat ajaran yang berisi pembebasan manusia dari berbagai penindasan. Islam hendak mengembalikan manusia dan mengangkat derajat kemanusiaannya sebagaimana mestinya. Namun demikian, Islam masih sering dituduh sebagai agama yang diskriminatif, ${ }^{1}$ khususnya terkait dengan status dan perlakuannya terhadap non muslim dan kaum perempuan. Dianggap diskriminatif, karena Islam melakukan pembedaan sikap dan perlakuan terhadap sesama manusia karena perbedaan agama yang dianutnya ataupun karena jenis kelamin. Tuduhan ini didasarkan pada teks hadis yang secara tekstual dianggap mengandung unsur diskriminatif.. Ada berapa hadis yang mengesankan bahwa Islam mengajarkan etika pergaulan Muslim baik dengan pemeluk agama lain maupun kepada orang yang berbeda jenis kelamin secara diskriminatif. Pada gilirannya, hadishadis ini mempengaruhi sikap dan perilaku umat Islam terhadap dua jenis makhluk tersebut dalam kehidupan sehari-hari.

Di antara hadis yang dianggap mengandung unsur diskriminatif terhadap non muslim tersebut misalnya hadis tentang perintah memerangi dan membunuh Yahudi dan Nasrani, larangan menikahinya, larangan meniru dan menyerupainya serta larangan memulai mengucapkan salam kepada mereka, dan lain-lain. Hadis tentang larangan memulai mengucapkan salam kepada Yahudi maupun Nasrani, untuk umat Islam yang hidup dalam masyarakat yang majemuk sungguh menjadi suatu problem tersendiri. Sikap diskriminatif seperti yang tercermin dalam hadis di atas kalau dipegangi secara tekstual akan melahirkan sikap keberagamaan yang eksklusif dan kaku. Dalam konteks pluralisme agama, hal ini berakibat negatif terhadap hubungan sosial antar umat beragama.

${ }^{1}$ Diskriminatif artinya yaitu pembedaan sikap dan perlakuan terhadap sesama manusia karena perbedaan agama yang dianutnya. Tim Penyusun, Kamus Besar Bahasa Indonesia (Jakarta: Departemen Pendidikan dan Kebudayaan Bekerjasama dengan Balai Pustaka, 1994), edisi 2, h.237. 
Walaupun hadis tersebut dianggap sahih $(s\} a b\} i>b\}$ al-isna $>d$ wa almatn), namun untuk konteks kekinian hadis ini hampir-hampir tidak menemukan relevansi dan tidak bisa diterapkan, khususnya di negara yang plural, kecuali dengan pendekatan dan paradigma baru. Demikian pula hadis tentang sikap Muslim yang harus memojokkan orang Yahudi dan Nasrani dipinggir jalan ketika bertemu.

Dari hadis-hadis seperti di atas, oleh sebagian Muslim dipahami sebagai norma sekaligus etika bergaul yang semestinya diterapkan oleh umat Islam terhadap umat beragama lain, yaitu perintah untuk bersikap keras, kasar dan larangan untuk berbuat baik terhadap non Muslim. Norma yang terkandung dalam teks di atas dianggap sudah tidak sesuai dengan semangat zaman, realitas dan konteks sosial dan budaya bahkan bertentangan dengan nilainilai universal Islam yang memberikan kebebasan kepada setiap individu untuk beragama ataupun tidak beragama. Dalam konteks tersebut, hadis-hadis yang sahih tidak bisa diamalkan (ma'mül bih) karena dianggap tidak sălih ${ }^{2}$ (relevan dan kontekstual) dengan realitas sosial yang ada.

Pada era kontemporer, tuntutan akan penghargaan terhadap harkat dan martabat manusia secara tak terelakkan bersentuhan dengan ide penegakan hak asasi manusia. Sikap-sikap diskriminatif terhadap manusia atas dasar SARA ditentang sebagai wujud pengakuan akan hak dasar umat manusia yang penting diapresiasi. Oleh karena itu, perlindungan akan hak-hak manusia dari pelanggaran-pelanggaran baik yang dilakukan oleh individu maupun lembaga merupakan realitas yang tak terbantahkan. ${ }^{3}$

${ }^{2}$ Kata șäliḥ secara etimologis berarti baik (kebaikan), sesuai dengan, dan relevan. Lihat, Hans Wehr, A Dictionary of Modern Written Arabic (ed) J. Milton Cowan (Wiesbaden, London: Otto Harrassowittz,1971), h. 522-523. Yang dimaksud dengan șalih disini dekat dengan teori pragmatis (the pragmatical theory of truth), yaitu bahwa kebenaran terletak pada sejauh mana fungsionalisasi suatu kebenaran dalam kehidupan praktis. Teori ini lebih menekankan pada arti kemanfaatan, (utility), kemungkinan dikerjakan (workability), dan akibat yang memuaskan (satisfactory result). Lihat, Endang Saefudin Anshari, Ilmu, Filsafat dan Agama (Surabaya: Bina Ilmu, 1991), h. 21-23; Noeng Muhajir, Filsafat Ilmu: Telaah Sistematis Fungsional Komparatif(Yogyakarta: Rake Sarasin, 1999), h. 14.

${ }^{3}$ Adnan Buyung Nasution, "Hak Asasi Manusia dalam Masyarakat Islam dan Barat" dalam Natsir Tamara dan Elza Peldi Taher (ed), Agama dan Dialog Antar Peradaban (Jakarta: paramadina, 1996), h. 108. 
Berangkat dari tuntutan adanya sistem relasi sosial yang humanis maka diperlukan kajian hadis dengan perspektif baru yang fungsional dan pragmatis. Kajian hadis tidak berhenti pada penelitian otentisitas dan kualitas hadis, tapi harus dilanjutkan pada pemahaman hadis dan kemungkinan pengamalannya. Bisa jadi suatu hadis dinyatakan sahih dalam konteks munculnya hadis tetapi ternyata tidak relevan untuk diterapkan dalam konteks ruang dan waktu yang berbeda. Artinya, mengkonstruksi pemahaman hadis, khususnya yang terkait dengan relasi sosial dengan basis relevansi dan kontekstualitas mendesak dilakukan.

Artikel ini memfokuskan kajian pada hadis-hadis tentang relasi umat beragama. Ada tiga pertanyaan yang diajukan: bagaimana gambaran redaksional hadis-hadis tentang relasi umat beragama, bagaimana konteks sosio-historis yang melatari kemunculannya dan bagaimana melakukan pembacaan yang konstruktif untuk konteks kekinian? Tujuan artikel ini yaitu mendeskripsikan secara komprehensif hadis-hadis tentang relasi umat beragama beserta konteks yang mengitarinya untuk kemudian dilakukan pembacaan ulang terhadap teks hadis untuk mendapatkan ajaran substantif dari Nabi dan menempatkan hadis sebagaimana mestinya.

\section{B. Pembahasan}

1. Protret Umat Beragama Masa Nabi Muhammad

Menurut catatan sejarah, pada saat agama Islam masuk ke jazirah Arab, masyarakat Arab saat itu sudah menganut berbagai agama, baik agama asli (agama tradisional Arab), maupun agama yang berasal dari pengaruh wilayah lain (seperti Yahudi dan Nasrani). ${ }^{4}$ Agama asli Arab merupakan suatu kepercayaan gabungan antara kultus nenek moyang, totemisme, fetisisme, politheisme-animisme, agama Sabi'un dan Majusi. Kepercayaan politeis merupakan agama mayoritas orang Mekkah, yang pernah dijumpai oleh Nabi Muhammad.

4 Lihat Syafiq A. Mughni, "masyarakat Pra Islam" dalam Taufik Abdullah (ed), Ensiklopedi Tematis Dunia Islam (Jakarta: Ichtiar baru Van Houve, 2002), h. 27-35, Lihat juga Salamah Noorhidayati, Hadis-hadis Diskriminatif terhadap Umat Beragama lain (Tulungagung: STAIN Press, 2010), h. 18-27. 
Yahudi merupakan komunitas agama yang paling intensif pergesekannya dengan komunitas Muslim di Madinah. Beberapa konsep teologis Islam sebagiannya diambil dari doktrin agama Yahudi, meskipun kaum Muslim menganggap kesamaan itu bukan berarti Islam diderivasi dari Yahudi tetapi lebih karena kesamaan sumber. Yahudi juga merupakan agama yang dalam konteks kontemporer Timur Tengah menentukan pola relasi dunia Islam dengan negara Israel yang hingga kini masih menyimpan masalah yang pelik.

Kelompok lain adalah pemeluk agama Nasrani ${ }^{5}$ yang juga cukup berpengaruh dalam struktur masyarakat di sekitar Madinah dimana Romawi merupakan penopangnya. Kristiani merupakan pemeluk agama mayoritas penduduk di dunia di mana hampir di semua wilayah ditemukan perjumpaan orang-orang Islam dengan penganut Kristen. Maka menjadi penting mempertimbangkan hubungan dengan agama ini melalui suatu etika hidup bersama yang baik.

Pemeluk agama Yahudi dan Nasrani inilah yang seringkali disebut dalam bahasa al-Qur'an sebagai Abl al-Kitäb, ${ }^{6}$ yaitu pengikut agama yang diberikitab suci. Akan tetapi ulama berbeda pendapat tentang rincian dan cakupan konsep abl al-kitäb. Secara global, pendapat mereka bisa dinyatakan bahwa yang termasuk abl al-kitāb adalah keturunan Israel (bani Israil), yaitu Yahudi dan Kristen yang punya garis keturunan Israel, siapapun yang mempercayai seorang Nabi atau kitab yang pernah diturunkan Allah, kelompok yang hanya percaya kepada șuhüf Ibrahim atau zabūr Daud, golongan alMajūs (Zoroaster) dan al-Säbi’in ( Sabian), bahkan Hindu, Budha dan Konfusian sebagai bagian dari abl al- kitäb. ${ }^{7}$

5 Agama Nasrani (Kristen) yang diketahui Muhammad adalah agama Kristen sebagaimana yang terdapat di Syiria (yang mencakup wilayah Syiria, Libanon, Israel, Yordania, Turki Tenggara, sebagian Irak dan padang pasir Arabia Utara). Lihat Van den End \& Christiaan de Jonge, Sejarah Perjumpaan Gereja dan Islam, (Jakarta: Sekolah Tinggi Teologi, 2001), h. 12.

${ }^{6}$ Terma abl al-kitab disebut sebanyak tiga puluh satu kali dalam al-Qur'an. Adapun rinciannya, Lihat Muhammad Galib M, Abl al-Kitab Makna dan Cakupannya (Jakarta: Paramadina, 1998), h. 20.

7 M. Azizan Sabjan dan Akhir Sakhirah M, "Konsep Ahl al-Kitab dalam Tradisi Islam", dalam Islamia, Tahun I No. 4 Januari-Maret 2005, h. 76- 77; M. 
Oleh karena itu, menjadi suatu hal yang wajar, jika Muhammad sebelum mendapatkan wahyu dari Allah yang berupa ajaran Islam telah lebih dahulu menjalin hubungan dengan para penganut agama-agama tersebut. ${ }^{8}$ Interaksi ini sudah dimulai sejak masa mudanya dan berlangsung sampai akhir masa hidupnya. Tidak cukup dalam ranah kultural, ${ }^{9}$ interaksi ini juga masuk ke ranah agama dan politik khususnya setelah Muhammad diangkat menjadi rasul yang kemudian hijrah ke Madinah. Maksudnya, Interaksi yang terjadi antara Islam dan agama semitik yang lain tidak hanya terjadi pada ranah teologis dalam kitab suci saja, tetapi juga dalam ranah politik kebangsaan. Dalam wilayah politik ini, Nabi Muhammad berperan sebagai seorang kepala negara. Dalam rangka memperkukuh Madinah sebagai suatu pemerintahan politis, Nabi saw membuat beberapa kebijakan. Pertama, Nabi mendirikan mesjid. Mesjid ini dipergunakan sebagai tempat ibadah, pusat kegiatan dakwah, pemerintahan, dan tempat musyawarah. Kedua, Nabi mempersaudarakan kaum Muhajirin dan kaum Anshar. Ketiga, membuat Piagam Madinah untuk mempersatukan berbagai suku, etnis, dan agama yang ada di Madinah demi menjaga keharmonisan, kerukunan, serta menjaga keamanan bersama dari serangan musuh. ${ }^{10}$

Quraish Shihab, Tafsir al-Mishbah, (Jakarta: Lentera Hati, 2003); Muhammad Abduh, Tafsir al-Qur'an al-Karim: Juz, Amma (Kairo: Dār Maktabi al-Șab, 1991), h. 101; M. Rasyid Ridha, Tafsir al-Manar (Beirūt: Dār al-Ma'rifah, 1994), h. 187190.

${ }^{8}$ Banyak fakta yang bisa dijadikan argumen dalam hal ini. Pada masa mudanya, Muhammad pernah bertemu dengan dua orang Nasrani yang telah membaca tanda kenabian pada diri Muhammad, yaitu Bukhara dan Nestor. Ibn Hisyām, as-Sìrah an- Nabawiyah. (Beirūt: Dār Ihyā̄' wa at- Turās̀ al- 'Arabīy, 1997), juz 1, h. 141. Budhi Munawar Rachman, dkk, "Dialog Antar Umat Beragama" dalam Taufiq Abdullah (ed), Ensiklopedi Tematis Dunia Islam (Jakarta: Ichtiar Baru van Hoeve, 2002), h. 212-213. Noorhidayati, Hadis-hadis Diskriminatif, h. 44.

9 Ibn Kasir menceritakan kesukaan Nabi saw memodel rambutnya seperti kebiasaan orang Yahudi dan Nasrani yang suka membiarkan rambutnya terurai lepas. Nabi juga sering meniru kebiasaan orang-orang Musyrik yang suka membelah tengah rambutnya, dan Asilla sering membantu melakukannya. Ibn Kà̇̄ì, al-Bidāyah wa an-Nihāyah, (Kairo: Dār al- Ḥādīis, 1992), juz IV, h. 20.

${ }_{10}$ Piagam Madinah juga menandai berdirinya Negara Madinah. Disebut dengan istilah lain "Konstitusi Madinab", Wasiqah al-Madinab", "Dustur al-Madinab" 
Piagam ini memuat tata hubungan di antara suku-suku yang bertikai di Madinah untuk dicarikan titik temunya tanpa menghilangkan keberadaan setiap kelompok atau etnis yang berbeda itu. Pada saat ini, Madinah tampil sebagai pusat komando penyebaran Islam. Kerukunan dengan penganut Yahudi dan Nasrani pun terjalin. Andai saja terjadi peperangan antara kaum muslimin dengan Yahudi dan Nasrani, itu disebabkan karena mereka melanggar Piagam Madinah secara sepihak. Demikianlah yang akhirnya mempengaruhi sikap dan pola interaksi Nabi saw terhadap komunitas lain yang tercermin dalam bentuk ungkapanungkapan verbal yang disampaikan.

\section{Hadis-hadis tentang Relasi Umat Beragama}

Penelusuran terhadap hadis Nabi tentang hubungan umat Islam dengan pemeluk agama lain menunjukkan bahwa ada dua sikap hadis terhadap komunitas non muslim: apresiatif-akomodatif dan kritis-konfrontatif. Adapun teks-teks hadis yang menunjukkan sikap apresiatif -akomodatif itu terlihat misalnya pada beberapa tema berikut:

Hadis tentang anjuran mendakwahkan Islam secara damai kepada abl al-kitab:

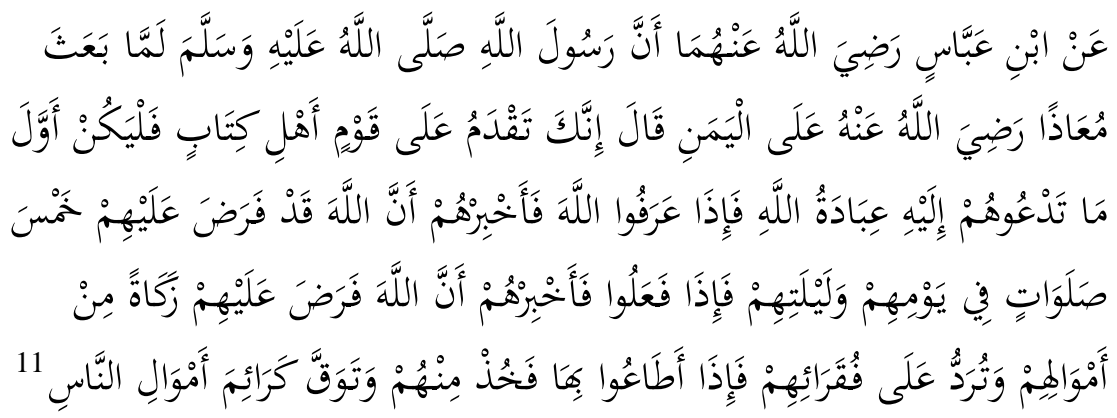

dan "Mitsaq al-Madinah". Terdapat perbedaan pendapat tentang pembuatan piagam Madinah; ada yang mengatakan pada tahun pertama hijrah dan sebagian lain berpendapat dibuat sebelum terjadinya Perang Badar; dan sebagian yang lain berpendapat setelah meletusnya perang Badar. Farid Abdul Khaliq, Fi al-Fiqh al-Islami: Mabadi' Dusturiyyat, (Mesir: Dar asy-Syuruq, 1968), h. 154; Budhy Munawar-Rahman,dkk. "Dialog Antarumat Beragama..”, h. 223

${ }^{11}$ Lihat Al-Imām Abi Abdillah Muḥammad bin Ismā'il bin Ibrāhim bin al-Mugīrah bin Bardizbah, al-Bukhāri, Șăḥiḥ al-Bukhārì, jilid 1, Juz 1, hadis no. 1365. 
Hadis lain yaitu cerita tentang praktik penghormatan Nabi terhadap jenazah Yahudi maupun abl al-kitäb, sebagaimana terekam dalam hadis berikut ini:

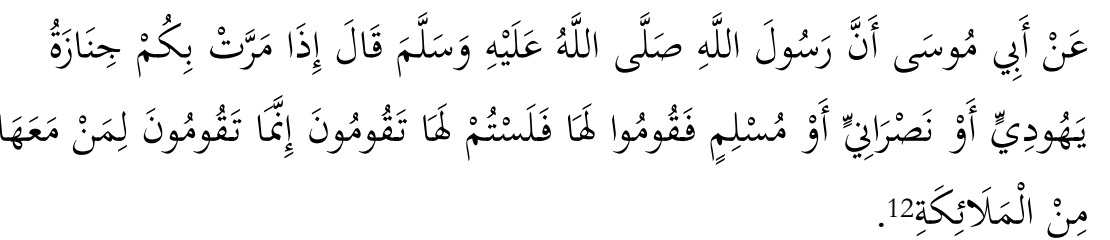

Dari Abu Musa bahwa Nabi saw bersabda: "Apanila di hadapan kalian lewat jenazah orang Yahudi atau Nasrani atau Muslim, maka hendaklah kalian berdir. Berdiri tersebut bukan untuk menghormati jenazah itu akan tetapi untuk yang bersamanya yaitu para malaikat.

Sementara hadis-hadis yang bersifat kritis-konfrontatif sangat banyak ditemukan dalam kitab hadis. Berdasarkan pelacakan hadis, ${ }^{13}$ maka hadis-hadis diskriminatif tersebut bisa dikategorisasikan ke dalam 3 bidang, yaitu: akidah, ibadah dan muamalah. ${ }^{14}$ Namun pengklasifikasian ini bukan merupakan kategori yang ketat dan baku, karena bisa jadi satu hadis masuk dalam dua kategori sekaligus.

Adapun hadis- hadis yang termasuk dalam bidang akidah misalnya hadis yang menyatakan kiamat tidak akan datang hingga kaum muslimin membunuh/memerangi Yahudi

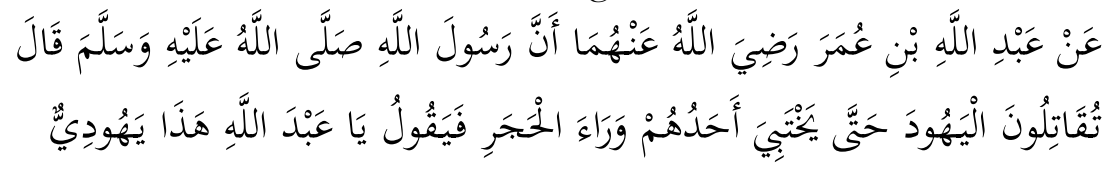

وَرَائي فَاقْتُلْهُ. 15

${ }^{12}$ Ahmad ibn Hanbal, Musnad Ahmad ibn Hanbal, hadis no.18671

13 Untuk pengumpulan hadis-hadis diskriminatif tersebut, penulis memanfaatkan kamus Al-Mu'jam al-Mufahras li Alfäz al-Hadïs an-Nabawì serta fasilitas CD Mausü'ah al-Hadïs asy-Syarif al-Kutub at-Tis'ah. Dalam mentakhrij tema-tema tersebut, penulis menggunakan secara acak dan bergantian dari keseluruhan metode takhrij yang ada ditambah dengan penggunaan fasilitas CD.

${ }^{14}$ Baca Noorhidayati, Hadis-hadis Diskriminatif..,h. 86- 106

15 Al- Bukhārī, Saḥịh al- Bukhāri, jilid 2, juz 3, h. 232. hadis no. 2708. 
Dari Abdillah Ibn Umar ra.,Rasulullah saw bersabda: "Kamu akan memerangi orang-orang Yahudi sehingga seseorang di antara mereka sembunyi di balik batu. Batu itu akan berkata, Wahai hamba Allah, ini ada orang Yahudi di belakangku, maka bunuhlah."

Hadis lain yaitu vonis terhadap Yahudi dan Nasrani akan masuk neraka, sebagaimaa hadis di bawah ini

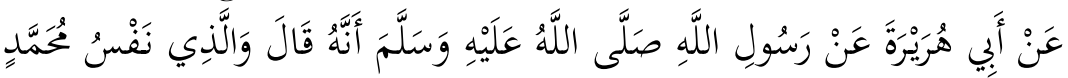

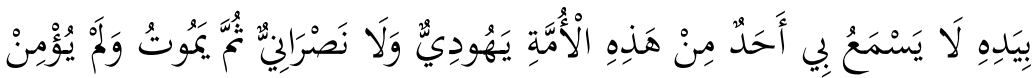

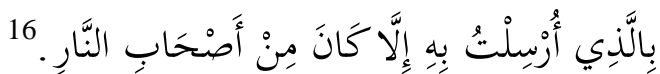

Dari Abu Hurairah dari Rasulullah saw, bahwa beliau bersabda: "Demi Allah yang jiwa Muhammad ada di tanganNya, tidak seorang pun dari umat ini, baik Yahudi maupun Nasrani, yang mendengarkanku kemudian ia mati dan tidak beriman dengan risalah yang aku bawa, kecuali ia mati sebagai penghuni neraka."

Hadis tentang perintah membunuh orang sampai ia mengucapkan "La Ilaha Illa Allab” juga termasuk dalam kategori ini. Adapun redaksi hadisnya adalah:

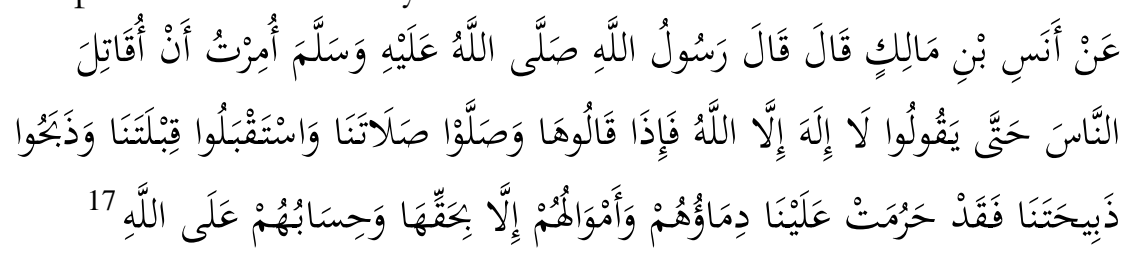

Dari Anas bin Malik, Rasulullah saw bersabda: "Aku diperintahkan untuk memerangi manusia hingga mereka mengucapkan "Tiada Tuhan selain Allah". Apabila mereka sudah mengucapkannya, sembahyang seperti sembahyang kita, menghadap kiblat kita, menyembelih seperti sembelihan kita, maka haramlah darah dan hartanya, kecuali secara haq, sedangkan perhitungannya adalah di sisi Allah."

16 Muslim bin Al-Hajjaj bin Muslim, Saḥḥ Muslim, (Dār al-Fikr: BeirutLibanon, tt), jilid 1, juz 1, h. 93, hadis no. 218

${ }^{17} \mathrm{Al}-\mathrm{Bukhāri,} \mathrm{Sahihh} \mathrm{al-} \mathrm{Bukhāri,} \mathrm{kitab} \mathrm{as-sholat,} \mathrm{hadis} \mathrm{no.} 379$. 
Demikian juga hadis tentang perintah mengusir orang Yahudi dan Nasrani sampai mereka bersedia memeluk Islam

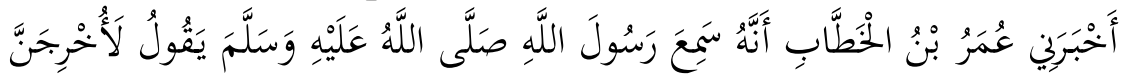

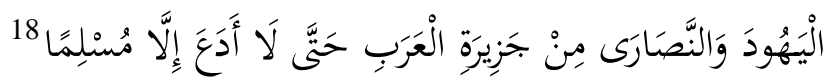

Umar bin Khațāa mendengar Rasulullah bersabda: "sesungguhnya aku akan mengeluarkan orang-orang Yahudi dan Nasrani dari Jazirah Arab hingga aku tidak akan membiarkannya kecuali dia menjadi seorang muslim.”

Sementara yang termasuk kategori diskriminatif dalam bidang ibadah misalnya hadis tentang pelaknatan Allah terhadap Yahudi dan Nasrani yang menjadikan kuburan sebagai masjid. Bunyi redaksinya sebagai berikut:

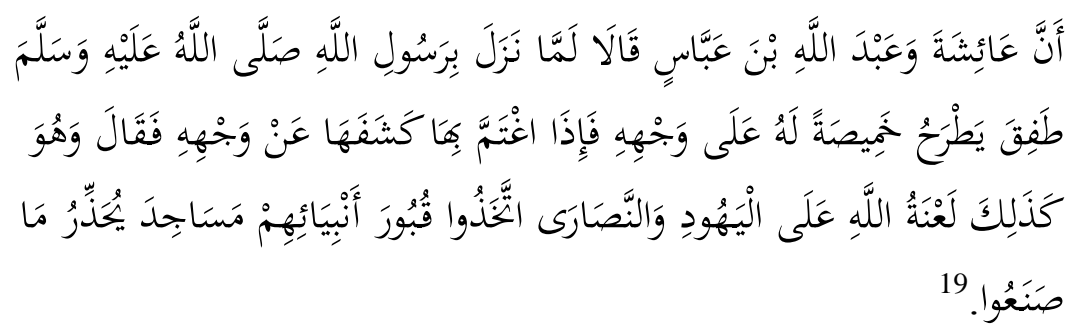

Aisyah dan Abdullah Ibnu Abbas ra, mereka berkata: ketika Rasulullah saw singgah, beliau mulai melemparkan selendang pada muka beliau, ketika selendang itu menutupi muka beliau, beliau membukanya dari muka beliau seraya bersabda dalam keadaan demikian:"La'nat (kutukan) Allah atas orang-orang Yahudi dan Nashrani karena mereka menjadikan kuburan nabi-nabi mereka sebagai masjid". Beliau mempertakutkan akan apa yang mereka perbuat.

Adapun hadis yang termasuk kategori diskriminatif dalam bidang muamalah seperti hadis tentang perintah untuk berbeda (tidak menyamai) dengan Yahudi dan Nasrani:

18Muslim, Sahih Muslim, kitab al-jihad wa as-siyar, hadis no 3313.

19 Al-Bukhari, Sahih al-Bukhari, hadis no. 417 


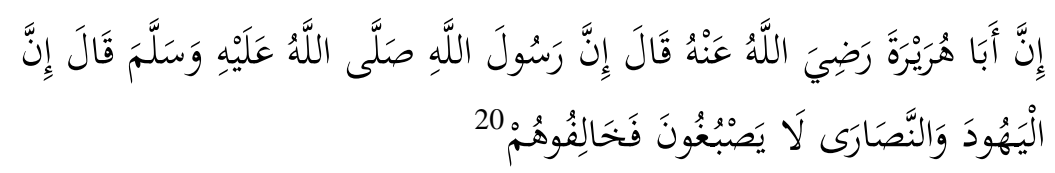

Dari Abu Hurairah ra, berkata, Rasulullah saw bersabda: "Sesungguhnya orang Yahudi dan Nasrani tidak mengecat rambutnya, maka berbedalah dengan mereka."

Hadis tentang larangan mengucapkan salam dan anjuran menghadang Yahudi dan Nasrani juga layak disebut dalam kategori ini. Adapun bunyi redaksinya adalah :

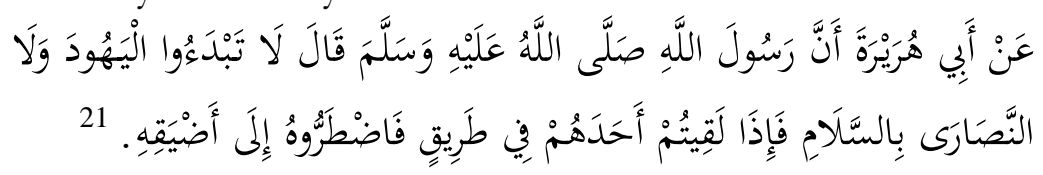

Dari Abu Hurairah ra, Sesungguhnya Rasulullah saw bersabda: "Janganlah kamu memulai mengucapkan salam kepada orang Yahudi maupun Nasrani, jika salahsatu dari kamu menjumpainya di jalan, maka desaklah dia ke tempat yang sempit."

\section{Pembacaan hadis dalam perspektif Historis-Sosiologis}

Suatu hadis muncul bukan dalam ruang hampa. Biasanya hadis merupakan respon atau reaksi terhadap problem masyarakat, yang mempunyai latar belakang dan kondisi sosio-historis tertentu. Relasi sosial yang terjadi antara umat Islam dengan umat beragama lain meniscayakan adanya dinamika tertentu. Dalam perjalanan sejarah, pola hubungan antara umat Islam dengan non muslim mengalami fluktuasi-ada saatnya dalam keadaan harmonis dan pada saat lain mengalami disharmoni. Umat Islam awal di Makkah hidup berdampingan dengan masyarakat pagan, yang politeistik. Pergaulan yang baik mengalami kerusakan ketika berkurangnya hegemoni Quraisy Mekah yang politeis terutama dalam ranah politik dan ekonomi. Secara umum, perjumpaan Islam dengan pemeluk kepercayaan paganisme (kaum was \ani/politheist) lebih bersifat konfrontatif-agresif. Sikap ini didasarkan atas seruan Islam untuk memberantas sifat dan sikap yang mencerminkan

${ }^{21}$ Muslim, Sahịh Muslim, jilid 4, juz 7, h.5, hadis no. 4030. 
kemusyrikan dan kekafiran. Kepercayaan akan adanya banyak Tuhan jelas bertentangan dengan ajaran tauhid, inti dari agama Islam.

Berbeda dengan penyikapannya terhadap penganut paganisme, Islam bersikap lebih lembut terhadap para pemeluk agama Yahudi, Nasrani dan termasuk di dalamnya Majusi, karena adanya titik temu dalam ajaran agama-agama. ${ }^{22}$ Titik temu ajaran yang dimaksud adalah karena kedua agama tersebut sama-sama mengajarkan ketauhidan (monoteisme). Walaupun bersumber dari asal yang sama, situasi kultural, politis, dan situasi lainnya menyebabkan adanya perbedaan sifat dan dasar monoteisme dari penganut ketiga agama tersebut. ${ }^{23}$

Di antara agama-agama besar dunia, Islam dan Kristen adalah dua agama yang dipeluk oleh sebagian besar penduduk dunia. Hubungan antara kedua agama tersebut juga sangat erat. Ketiga agama ini dikenal dengan sebutan agama Ibrahimi (Abrahamic Religions/ al-adyān al-Ibrabimiyyab) ${ }^{24}$ karena akar sejarah ketiga agama tadi bertemu pada Nabi Ibrahim. Jika diibaratkan manusia, ketiga agama tersebut dapat disebut "tiga serumpun" atau "tiga bersaudara", dengan agama Yahudi sebagai yang tertua dan Islam sebagai agama yang termuda. Jadi, ketiganya masih satu keluarga. Tapi ibarat kehidupan dalam sebuah keluarga, di samping terdapat banyak persamaan dan kerjasama, hubungan antara ketiga agama tadi, memperlihatkn segi positif sekaligus negatif.

Secara singkat, sikap muslim awal terhadap kaum Yahudi dan Nasrani (abl al-Kitäb) menunjukkan sikap yang relatif toleran. Berdasarkan pengakuan eksplisit adaya suatu dasar umum yang sama-sama dimiliki oleh kaum muslim, dan Abl al-Kitāb, Islam tidak pernah memiliki kepercayaan bahwa kaum Yahudi dan Nasrani itu

22 Abd al-Mu’ți Muḥammad Bayūmī, Al-Isläm fì al-Qarn al-Hādìis wa al'Isyrin Ru'yah 'Așriyyah li al-Islàm, (Mesir: Nahḍah Misr, 2010), h. 209.

23 Adeng Muchtar Ghazali, Agama dan Keberagamaan Dalam Konteks Perbandingan Agama, (Bandung: Pustaka Setia, 2004), h. 89.

${ }^{24}$ Ghazali, Agama dan Keberagamaan, h. 86. Alī Muḥammad Sālí Abdullah, al-Hiwār ad-Dinìy al-Ibrābimìy fì Mì̄àn al-Qur'ān, (Kairo: Dār as-Salām, 2007. 
tidak akan memperoleh penyelamatan jika mereka tidak berpindah kepada agama Islam. ${ }^{25}$

Sejarah menunjukkan bahwa pada mulanya hubungan antara Islam dan Kristen berlangsung baik. Islam selalu menghormati agama Kristen sebagaimana menghormati agama-agama lain. Setiap muslim menjunjung tinggi Jesus atau Isa sebagai seorang Nabi sebagaimana juga menjunjung tinggi nabi-nabi lain. Bersama-sama agama Yahudi, Islam menempatkan orang-orang Kristen pada posisi yang sangat terhormat dan mulia, Abl Al-Kitäb, pemilik wahyu atau kitab. ${ }^{26}$

Pada dekade-dekade awal ini, Nabi memberikan sejumlah contoh sikap toleran terhadap penganut agama lain dan dilanjutkan pada masa pemerintahan khalifah-khalifah pertama. ${ }^{27}$ Namun, hubungan baik antara Islam dan Kristen tidak bertahan lama. Setelah berdirinya kekuasaan politik Islam, perbedaan antara kaum muslim dengan kaum lain mulai terbuka terutama setelah Islam melakukan ekspansi ke berbagai daerah untuk menyebarkan Islam. ${ }^{28}$ Sesudah Islam menyebar keluar semenanjung Jazirah Arab, orang-orang Kristen mulai memandang Islam sebagai sebuah fenomena baru yang memunculkan banyak masalah dan mengancam eksistensi mereka, baik dari segi teologis, intelektual

25 Abdul Aziz Sachedina, Kesetaraan Kaum Beriman, (Jakarta: Serambi, 2002), h. 122-123.

26 Sebagaimana yang telah di jelaskan dalam Alquran surat Al-Hajj ayat 78, "Dan berjuanglah pada (jalan) Allah dengan sekuat-kuat perjuangan, dialah yang memilih kamu dan tiada dijadikan-Nya atas kamu kesempitan dalam agama. Agama Bapak kamu ibrabim. Dia telah menamakan kamu muslimin, dari dulu dan dalam (Alquran) ini supaya Rasul menjadi saksi (juru penerang dan teladan) bagi kamu dan kamu menjadi saksi bagi manusia....".

${ }^{27}$ Contoh teladan dalam hal ini bisa dilacak dalam karya-karya sejarah seperti Ibn Sa'ad, Thabaqat al-Kubra, (Beirut: Dar Sadir, 1960/1380) vol 1, h. 358; Philip K.Hitti, The Origin of the Islamic State (New York: Columbia University, 1916), vol.1, h. 109. Imam Bukhari, dalam Sahihnya meryebutkan perintah yang diberikan kepada Muaz bin Jabal dan Abu Musa ketika Nabi saw mengutus mereka ke Yaman: "Perlakukan orang dengan baik, dan bukan dengan kekerasan; penubi diri mereka dengan kabar gembira dan bukan dengan kehawatiran. Saling mengikutilah dan jangan terpecah-pecah." Bukhari,kitab jihad, hadis no.275. Muḥammad Ibn Jarīr aț-Ṭabārī, Tärikh ar-Rusul wa al-Mulūk (Kairo: Dār alMa'arif, 1960), vol 1, h. 2922,

28 Sachedina, Kesetaraan, h. 124. 
maupun politik. Dari sinilah mulai muncul gesekan-gesekan yang sebenarnya dipicu oleh faktor kepentingan politis kemudian dicarikan klaim keagamaan. Dalam debat teologis dan intelektual yang muncul memperburuk hubungan antara pemeluk kedua agama tersebut. Akhirnya, hubungan antara Islam dan Kristen, sering memperlihatkan segi-segi negatif.

Sementara hubungan Islam- Yahudi secara intens terjalin sejak Nabi saw hijrah ke Madinah. Hubungan ini lebih bersifat politis sebab jauh sebelum Nabi hijrah, di Madinah sudah terdapat orang Yahudi, bahkan mereka menempati posisi yang berpengaruh. Karena benturan politik dan ekonomi, hubungan antara umat Islam dan Yahudi tidak berjalan secara mulus. Kedua umat ini terlibat dalam berbagai konflik. Konflik ini disebabkan oleh karena Umat Yahudi menjalin hubungan dengan pihak yang memusuhi Nabi seperti Abdullah bin Ubay, tokoh terkemuka di kalangan Arab Madinah yang merasa tersingkir karena kehadiran Nabi. Selain dengan kelompok ini, umat Yahudi juga menjalin dengan orang Quraisy yang tetap ingin menyingkirkan Nabi dan juga dengan suku-suku Arab lain yang belum mau menerima kepemimpinan Nabi saw. Muncul pula konflik fisik antara umat Islam dan Yahudi bermula dari kasus Ka'ab bin Asyraf, putra seorang Arab dari Bani Tayy, yang menikah dengan wanita Yahudi dari bani Nadir. Konflik yang lain juga terjadi antara umat Islam dengan Bani Qainuqa, Bani Nadir dan Bani Quraizah. ${ }^{29}$ Berbagai konflik ini merupakan lembaran hitam dalam hubungan umat Islam dan umat Yahudi yang pada kemudian hari menentukan pola relasi antara pemeluk kedua agama ini.

Dengan demikian bisa dinyatakan bahwa relasi Muslim dengan pemeluk agama dan kepercayaan lain di Makkah, terlebih di Madinah mengalami fluktuasi, antara harmonis-disharmonis atau kooperatif-konfrontatif. Maka, sudah selayaknya hadis-hadis yang muncul juga tidak terlepas dari dan merupakan gambaran terhadap problem-problem yang bersifat spesifik dalam konteks kehidupan tersebut. Oleh karena itu, telaah hadis dengan mempertimbangkan

29 Adapun contoh bentuk konflik, baca selanjutnya Budhy MunawarRahman,dkk. "Dialog Antarumat Beragama".h. 223- 224 dan Noorhidayati, Hadis-hadis Dikskriminatif, h. 58-59 
faktor-faktor historis-sosiologis sangat diperlukan. Pemahaman hadis dilakukan dengan cara menempatkan hadis dalam konteks kesejarahan, sebagai sebuah teks yang bersifat spesifik dan mengambil nilai-nilai dasar dan prinsip-prinsip universal untuk diterapkan dalam konteks dan budaya yang berbeda. ${ }^{30}$

\section{Pembacaan Hadis dalam Perspektif Rekonstruktif}

Pengetahuan tentang dinamika sosial kehidupan umat beragama sebagaimana dipaparkan di atas berguna dalam melakukan pemahaman hadis yang lebih konstruktif untuk konteks kekinian. Hadis-hadis tentang relasi umat beragama harus dibaca dengan menggunakan pendekatan humanis-kontekstual. Pendekatan humanis dimaksudkan untuk memandang dan memperlakukan umat non muslim sebagai sesama manusia dengan segala hak yang melekat padanya. Sementara pendekatan kontekstual adalah melakukan pemahaman hadis dengan mempertimbangkan konteks yang mengitarinya. Pendekatan ini ditempuh dengan cara menggali konteks awal munculnya hadis untuk kemudian mencari korelasi dan titik temu antara konteks awal dan konteks kekinian dengan tetap berpegang pada prinsipprinsip dasar dan universal ajaran Islam. Dengan menggunakan dua pendekatan ini diharapkan hadis-hadis yang secara redaksional dianggap tidak relevan dengan konteks kekinian akan tetap bisa diamalkan setelah dilakukan proses kontekstualisasi.

Sebagaimana tercatat dalam dalam sejarah bahwa pada awalnya, kaum Yahudi bersama-sama dengan suku lainnya menerima piagam Madinah. Mereka menerima syarat untuk saling melindungi kota Madinah ketika diserang musuh. Namun karena kepentingan sesaat, mereka mulai mengkhianati umat Islam dengan bergabung dan bersekutu dengan kelompok kaum musyrikin yang akan menyerang Madinah. Yahudi berkali-kali melakukan tindakan makar bersama orang kafir Musyrik untuk mencelakakan Nabi bahkan membunuhnya. ${ }^{31}$ Perbuatan yang demikian, dalam dunia

${ }^{30}$ Fazlur Rahman, Islam dan Modernitas, ter. Aksin Muhammad (Bandung: Pustaka, 1985), h.7.

${ }^{31}$ Lihat perilaku mereka ini dalam, Abd ar-Rahmān Muhammad Abd arRahmān, Uslūb al-Qur'ān al-Karìm fì Da'wab Abl al-Kitāb ( Mesir: Dār al-Yaqīn, 2009), h. 258-262. 
modern, bisa dijelaskan dalam konteks penghianatan. Pengkhianatan merupakan sesuatu yang sangat dicela dalam Islam pun dalam agama-agama lain. Apa yang dilakukan oleh orang Yahudi Madinah yang bergabung dengan tentara musyrikin untuk menyerang Madinah adalah bentuk pengkhianatan dan tindakan subversif. Ini sangat membahayakan keamanan negara (Madinah) saat itu. Mengingat umat Yahudi adalah umat yang paling sering melakukan penghianatan, maka tidak mengherankan kalau Nabi memberikan kutukan yang keras terhadap perilaku mereka, misalnya dengan memerintahkan untuk memerangi dan mengusirnya. Perintah itu juga bisa dipahami dalam konteks perintah memerangi kaum musyrikin dan munafiqin serta umat lainnya manakala diserang dan diancam. Umat Islam diijinkan untuk melakukan upaya-upaya seperlunya demi pertahanan diri32 dengan cara-cara yang tidak melampaui batas. ${ }^{33}$

Hadis tentang penyerangan umat non muslim tersebut bila dikaitkan dengan daerah yang masyarakatnya heterogen dan hidup dalam suasana damai perang seperti Indonesia hampir tidak menemukan relevansinya.. Prinsip kebebasan beragama menempati posisi yang sangat tinggi dalam Islam dan Indonesia. Umat Islam dilarang melakukan pemaksaan kepada kelompok lain untuk mengikuti ajaran Islam. Hal ini sejalan dengan hadis apresiatif yang menyuruh mendakwahkan dan mengenalkan ajaran Islam tanpa melakukan paksaan atau ancaman. Prinsip semacam ini menjadi sendi utama dakwah Islam. Namun apabila mereka menolak dakwah dan melakukan tindakan yang akan membahayakan dan mengancam umat Islam, maka kepada umat Islam diberikan hak membela diri. Demikianlah prinsip-prinsip utama ajaran Islam yang harus tetap diterapkan dalam konteks kehidupan modern seperti saat ini.

Terhadap hadis tersebut, ada pandangan yang menghubungkan dengan tanda-tanda kenabian Muhammad SAW yaitu kemampuan memprediksi kejadian di masa yang akan datang. Atau dengan kata lain hadis ini termasuk hadis prediktif dari Nabi SAW (berdasarkan informasi wahyu) tentang akan terjadinya

${ }^{32} \mathrm{QS}$ al-Anfal: 60.

${ }^{33} \mathrm{QS}$ al-Baqarah: 190 
peperangan antara kaum Muslimin dengan Yahudi dan Nasrani. Dalam pandangan Yusuf al-Qaradawi, hadis semacam ini perlu dipahami dengan sangat hati-hati. Pemahaman yang tidak tepat akan melahirkan kesimpulan yang kurang tepat mengenai Islam sebagai agama yang cinta perdamaian. Bahkan boleh jadi hadis ini akan memicu timbulnya konflik antara agama yang berkepanjangan. Menurutnya, hadis "ramalan" seperti ini dalam faktanya ada yang terlah terjadi, ada yang belum terjadi, bahkan mungkin saja ada yang tidak pernah terjadi. Dengan demikian maka hadis ini lebih tepat dipahami sebagai informasi kepada Islam, Yahudi dan Kristen agar bersikap hati-hati dalam melakukan hubungan pergaulan. Intinya, apa yang "diramalkan" oleh Nabi diharapkan dan harus diusahakan oleh ketiga agama samawi tersebut jangan sampai terjadi.

Hadis tentang perintah memerangi orang Yahudi dan Nasrani serta mengusirnya dari kampung halaman sampai menyatakan kesediaannya masuk Islam dan justifikasi masuknya abl al-kitab ke dalam neraka lebih tepat diletakkan dalam konteks peperangan yang telah dan sedang terjadi antara umat Islam dengan umat lainnya. Kalaupun umat Islam terpaksa memilih jalan perang, maka prinsip utama dan pertama yang harus ditegakkan adalah bahwa perang ini merupakan perang yang secara syariat dibolehkan baik karena umat Islam mempertahankan diri dari serangan orang lain atau dalam konteks membalas perlakuan kasar dan jahat yang diberikan oleh pihak lain kepada umat Islam dan bukan perang yang didahului oleh umat Islam sebagai pihak yang agresif. Yang kedua, memahami hadis ini juga perlu memperhatikan semangat damai Islam berhubungan dengan umat lain yang menginginkan perdamaian. Umat Islam hanya diperbolehkan melakukan tindakan keras terhadap orang yang mengganggu dan melakukan penyerangan. Ketiga, dalam konteks masyarakat yang majemuk, perbedaan keyakian merupakan sesuatu yang mesti disikapi dengan hati lapang. Dalam berdakwah dan bersikap, umat Islam dituntut melakukannya secara elegan dan terbuka untuk mau mengakui perbedaan dan tetap berpegang pada prinsip kebebasan beragama.

Sementara terkait dengan hadis yang menyatakan bahwa Yahudi dan Nasrani masuk neraka, maka hadis ini perlu dilihat dari beberapa hal: pertama, al-Qur'an tidak pernah mengeneralisir bahwa 
pada suatu kaum semua baik atau buruk, semua sama, masuk neraka atau masuk surga; Islam justru selalu menegaskan bahwa kebaikan dan keburukan selalu dilihat dari amal dan takwanya, bukan bentuk-bentuk lahiriyah. Kedua, Islam melalui al-Qur'an menegaskan bahwa abl al-kitab variatif, ada yang beriman dan ada yang kafir. Ketiga, gambaran tentang sifat-sifat abl al-kitab dalam alQur'an juga berisi gambaran yang dinamis. Kadangkala bersikap memuji, kadang bersifat kritis dan ini yang lebih banyak dan kadang bersifat netral-informatif. ${ }^{34}$

Secara positif al- Qur'an menggambarkan bahwa di antara abl al-kitab ada yang baik dan layak mendapatkan pahala di sisinya sebagai balasan atas amal perbuatan. Kritik yang keras kepada mereka merupakan bukti bahwa ada di antara mereka yang menyeleweng dari jalan yang benar baik dilihat dari ajaran agama mereka sendiri maupun ajaran moral umum. Sebagaimana disebut al-Qur'an tentang adanya pengakuan orang Nasrani tentang Isa (Yesus) dan orang Yahudi tentang Uzair sebagai anak Tuhan.

Kandungan makna hadis di atas mencitrakan kesan negatif terhadap Yahudi dan Nasrani sebagai suatu komunitas etnis. Pada hadis ini, Yahudi dan Nasrani sudah divonis sebagai calon ahli neraka. Hadis tersebut tidak harus dipahami secara skriptualis dan tekstual karena akan bertentangan dengan nilai-nilai toleransi yang dibangun Islam sebagai pondasi untuk menciptakan kerukunan antar umat beragama. Tetapi, yang diperlukan oleh umat Islam untuk menyikapi hadis konfrontatif tersebut adalah sikap toleransi yang tinggi dalam relasi sosial dan menghindari paradigma truth of claim, ${ }^{35}$ yang seolah-olah hanya Islam saja yang berhak masuk surga.

${ }^{34}$ Lihat Muhammad Ghalib, Abl Kitab Makna dan Cakupannya (Jakarta: Paramadina, 1998), h. 98-106.

35 Setiap agama memiliki kebenaran. Keyakinan tentang yang benar itu didasarkan pada Tuhan sebagai satu-satunya sumber kebenaran. Dalam tataran sosialogis, klaim kebenaran berubah menjadi simbol agama yang dipahami secara subjektif, personal, oleh setiap pemeluk agama. Ia tidak lagi utuh dan absolut. Pluralitas manusia menyebabkan wajah kebenaran itu tampil beda ketika akan dimaknakan dan dibahasakan. Sebab, perbedaan ini tidak dapat dilepaskan begitu saja dari berbagai referensi dan latar belakang yang diambil orang yang meyakininya dari konsepsi ideal turun kebentuk-bentuk normatif yang bersifat kultural. Ini yang biasanya digugat oleh berbagai gerakan 
Dengan sikap toleransi ini banyak hal yang dapat dibangun dan dikerjakan untuk mewujudkan kemaslahatan umat. Persoalan apakah Yahudi dan Nasrani akan masuk surga atau tidak, dalam pandangan penulis tidak hanya diukur oleh hadis tersebut, tetapi juga harus dilihat dalil-dalil lain terutama al-Qur'ān yang menjelaskan persyaratan dan variabel-variabel penting seseorang bisa masuk surga. Pada beberapa ayat dalam al-Qur'ān didapati penjelasan Allah SWT bahwa orang yang beriman dan beramal saleh dipastikan akan masuk sorga. ${ }^{36}$ Walaupun hadis tersebut menegaskan tempat yang pasti bagi Yahudi dan Nasrani adalah neraka, menurut penulis bisa difahami bahwa penyebab itu bukan ke-Yahudi-an atau ke-Nasrani-annya, melainkan karena sikap dan perilaku yang ditampilkan. 37

Demikian juga dengan hadis tentang perintah mengusir Yahudi dan Nasrani dari jazirah Arab perlu diletakkan dalam pemahaman yang historis dan logis. Hadis ini dapat dan harus dipahami dalam konteks perilaku abl al- kitab yang suka menyeleweng dari kebenaran, memusuhi umat Islam dan Nabi, persekutuan mereka untuk mengkianati dan memusuhi Nabi saw Nabi. Hal ini sesuai dengan apa yang dijumpai Nabi di masa hidup Nabi. Oleh karenanya nisa dinyatakan bahwa hadis ini memiliki konteks yang khusus. Konteks itu adalah pertama, akibat tindakan kaum Yahudi yang selalu menelikung dari dalam sebagai anggota suatu komunitas di Madinah. Pengusiran terhadap mereka secara logis bisa dibenarkan sebagai konsekwensi atas pengkhianatan yang mereka lakukan Kedua, terhadap umat Nasrani atau Kristen, tindakan ini harus mendapatkan legitimasi dan dasar yag kuat dan sahih dari al-Qur'an. Pada masa Nabi tindakan pengusiran hanya berlaku untuk kaum Yahudi. Bisa jadi, apa yang disabdakan Nabi

keagamaan pada umumnya. Mereka mengklaim telah memahami, memiliki, bahkan menjalankan secara murni dan konskuen nilai-nilai suci itu.

36 QS. Al-Haji : 23; QS. Al-Tagābun : 9; QS. Al-Bayyinah : 7-8; QS. AlNisa : 57; QS. Al;-Kahfi : 107; QS. Luqmān : 8.

${ }^{37} \mathrm{Hal}$ ini lebih dipertegas lagi oleh firman Allah SWT dalam surah alBaqarah ayat 62: "Sesunggubnya orang-orang yang beriman dan orang-orang Yahudi, Nasrani, dan Shabiin, adalah orang yang beriman kepada Allah dan kepada Hari Akbir dan beramal saleh, maka bagi mereka pahala dari Tuhan mereka dan tidak ada ketakutan bagi mereka lagi tidak bersedib". 
ini merupakan strategi yang harus dilaksanakan oleh para pemimpin politik negara Islam di masa berikutnya untuk menyelamatkan diri dari gangguan internal. Ini perlu dilacak dalam sejarah secara baik agar kita bisa memahami dan meletakkan masalah ini secara kontekstual dan proporsional.

Sementara hadis tentang laknat Allah kepada orang Yahudi yang menjadikan kuburan para nabi sebagai masjid bisa dijelaskan sebagai berikut. Sebenarnya, tidak ada korelasi antara kebencian Nabi terhadap Yahudi dan Nasrani dengan hadis ini, Nabi hanya menyatakan bahwa Yahudi dan Nasrani akan dilaknat Tuhan ketika menjadikan kuburan para Nabi sebagai masjid. Ketika hal itu tidak terjadi maka tidak ada alasan bagi Nabi untuk melaknat Yahudi dan Nasrani, dan oleh karena peristiwa itu terjadi pada masa Nabi, maka sifatnya kasuistik dan temporal yang tidak bisa digeneralisasi. Namun demikian, jika nilai universal yang dikedepankan, bahwa hadis ini mengandung ajaran dasar tentang larangan perbuatan syirik dalam bentuk apapun dan dilakukan oleh siapapun, tidak terkecuali umat Islam. Laknat Allah melalui lisan Nabi ini juga bisa diperlakukan bagi umat Islam yang melakukan praktik menjadikan fenomena ziarah kubur sebagai pengkultusan terhadap tokoh-tokoh tertentu

Jika mengandaikan kesahihan isi dari hadis ini, maka pemahaman terhadap hadis ini perlu memperhatikan beberapa hal yang terkait: pertama, laknat atau kutukan atau celaan harus diberikan kepada orang yang dalam praktiknya telah jatuh ke dalam kemusyrikan. Kemungkinannya Nabi melarang ini disebabkan mereka telah melakukan praktik yang tidak aman dari syirik. Kedua, dengan memperhatikan redaksi hadis kedua yang memakai kata "Nabi mengingatkkan apa yang mereka lakukan", sesungguhnya memberi isyarat bahwa larangan Nabi berlaku bagi umat Islam. Hal ini, sekali lagi, disebabkan oleh sikap kehati-hatian dalam masalah syirik yang memang banyak terjadi berkaitan dengan perilaku orang yang demikian menghormati orang yang telah mati, termasuk para Nabi, para wali, ulama salih. Dengan menjadikan kuburan sebagai masjid memungkinkan orang jatuh ke dalam pendewaan ahli kubur yang dianggap keramat dan akan memalingkan mereka dari taubidullah. 
Hal yang sama berlaku pada hadis tentang larangan Nabi menyerupai orang Yahudi dan Nasrani. Hadis larangan meniru dan menyerupai Yahudi dan Nasrani, perlu dikritisi dan diverifikasi melalui dalil-dalil lain. Kegiatan tiru meniru, baik oleh orang Islam terhadap Yahudi dan Nasrani maupun sebaliknya, ketika antara dua komunitas itu telah terjadi interaksi dan asimilasi, merupakan sesuatu yang sangat sulit dihindari. Hal ini menjadi sesuatu yang sangat absurd ketika dewasa ini orang Islam dengan non Muslim hidup berdampingan bahkan menjalin kerjasama dalam berbagai bidang kehidupan.

Dalam konteks masa lalu, larangan meniru dan menyerupai Yahudi adalah masalah identitas bagi masyarakat yang baru terbentuk. Identitas, dalam segala bentuknya di masyarakat sangat dibutuhkan ketika terjadi hal-hal yang mengganggu harmonitas antar kelompok. Dalam keadaan kacau, maka identitas berfungsi untuk menandai posisi seseorang dan pembeda antara satu kelompok dengan kelompok lainnya. Penulis lebih condong untuk mengaitkan hadis ini dengan konteks perilaku menyimpang yang dilakukan umat Yahudi dan penegasan identitas tersebut. Pemahaman yang demikian ini dilakukan dengan beberapa pertimbangaan di antaranya, lebih berorientasi kepada tujuan yang diungkapkan oleh Nabi, lebih berorientasi kepada kepentingan yang lebih bermakna, selain tentu saja bertujuan untuk memberikan identitas. Hal ini dilakukan oleh Nabi dalam rangka penjelasan kepada sahabat bahwa sebagai agama, Islam mempunyai simbolsimbol tertentu yang membedakan dengan agama-agama lainnya.

Selain itu, dengan hadis tersebut Nabi ingin mendorong kepada para sahabat untuk mengembangkan kreatifitas berpikir secara dinamis. Hal ini bisa dilihat dari proses dialog yang berlangsung ketika mereka mengusulkan beberapa alternatif dalam teknis pemberitahuan tibanya waktu shalat dan panggilan bagi orang yang melakukan sal;at. Secara filosofis, azan itu bukan hanya sekedar pemberitahuan untuk waktu shalat, melainkan untuk lebih mengingatkan manusia akan kemahabesaran Allah SWT sebagai alkhäliq sekaligus menyadarkan manusia sebagai makhlük yang kecil dan hina di hadapan-Nya.

Sementara terkait dengan larangan mengucapkan salam bisa dijelaskan sebagai berikut. Salam (kedamaian dan keselamatan) 
merupakan salah satu ajaran penting dalam Islam. Ucapan salam merupakan salah satu identitas Islam dan keIslaman. Banyak sekali Hadis yang menganjurkan agar kaum Muslim menebarkan salam, bahkan terdapat satu ayat dalam al-Qur'ān yang memerintahkan agar menjawab salam dengan jawaban yang lebih baik dari pemberi salam. ${ }^{38}$ Pernyataan salam "Assalamu'alaikum" oleh sebagian ulama dianggap sebagai ungkapan yang sifatnya ta'abbudi dan karenanya mereka melarang mengucapkannya kepada orang non muslim karena dianggap mendoakan dan mengakui kebenaran agama mereka. Namun, kalau dikembalikan kepada makna generiknya bahwa salam adalah doa keselamatan dan kedamaian bagi orang lain, maka tidak ada salahnya kalau salam itu disampaikan kepada sesama manusia tanpa melihat agama dan jenis kelamin. Dalam konteks muamalah, salam ini penting dalam rangka memelihara kerukunan umat beragama dan sesama manusia. Hal ini semestinya tidak akan mengganggu keyakinan Islam atau merusak kemusliman seseorang. Mengucapkan salam atau menebar kedamaian merupakan merupakan ajaran Islam yang lebih berdimensi sosial daripada akidah.

Jika ditelaah secara sosiologis, pada dasarnya agama membawa misi sebagai pembawa kedamaian dan keselarasan hidup, baik secara internal umat beragama maupun secara eksternal dengan pemeluk agama lain. Alih-alih sebagai pemersatu sosial, tidak jarang justru agama sebagai unsur konflik. Hal ini disebabkan oleh adanya truth claim pada tiap-tiap pemeluknya, di samping pola pemahaman teks keagamaan yang tekstualis. al-Qur'ān dan hadis sebagai wahyu Allah SWT, dalam pandangan dan keyakinan umat Islam adalah sumber kebenaran mutlak, namun itu tidak akan tampak manakala tidak dipahami secara tepat. Setiap agama membawa misi sebagai pembawa kedamaian dan keselarasan hidup, bukan saja antar manusia, tetapi juga antar sesama makhluk Tuhan. Dalam tataran historis, misi agama tidak selalu artikulatif. Selain sebagai alat pemersatu sosial, agama pun menjadi sumber konflik. Dua unsur itu menyatu dalam agama. Mungkin pernyataan ini agak berlebihan. Tetapi, jika melihat perjalanan sejarah dan realitas di muka bumi ini, pernyataan itu menemukan landasan historisnya

${ }^{38}$ QS. Al-Nisa: 85 
sampai sekarang. Persoalannya, bagaimana realitas itu bisa memicu para pemeluk agama untuk merefleksikan kembali ekspresi keberagamaannya yang sudah sedemikian mentradisi dalam hidup dan kehidupannya.

Berkaitan dengan itu, salah satu yang menjadi problem paling besar dalam kehidupan beragama dewasa ini, yang ditandai oleh kenyataan pluralisme, adalah bagaimana teologi suatu agama mendefinisikan diri di tengah-tengah agama lain, dengan semakin berkembangnya pemahaman mengenai pluralisme agama, berkembanglah suatu paham teologia religionum. Paham ini menekankan semakin pentingnya dewasa ini untuk berteologi dalam konteks agama-agama. Atau, bisa dikatakan bahwa memahami pluralitas agama dan budaya merupakan bagian dari memahami agama, sebab memahami agama pada dasarnya juga memahami kebudayaan masyarakat secara menyeluruh. Langkah bijaksana bagi setiap umat adalah belajar dari kenyataan sejarah. Yaitu sejarah yang mendorong terwujudnya masyarakat pluralis, toleran dan integratif. Agenda yang perlu diluruskan oleh Islam Indonesia adalah mengubah pluralisme sebagai ideologi konkret. Untuk mewujudkan cita-cita ini, dituntut peran negara yang positif dalam memperlakukan agama. Agama bukan hanya sebagai intrumen mobilisasi politik, tetapi yang lebih penting adalah memperlakukannya sebagai sumber etika dalam interaksi, baik di antara sesama penguasa maupun antara penguasa dengan rakyat.

\section{Penutup}

Berdasarkan pembahasan di atas, dapat ditarik beberapa kesimpulan. Pertama, secara tipologis, hadis-hadis tentang relasi umat beragama bisa dipetakan dalam dua kategori. Yang pertama, dari segi sikap, hadis-hadis tersebut menunjukkan pada dua sikap yaitu apresiatif-akomodatif dan kritis-konfrontatif; yang kedua, dari segi materi yang dikandung, hadis-hadis tersebut mencakup pada tiga bidang, yaitu akidah, ibadah dan muamalah.

Kedua, suatu hadis muncul sebagai respon atau reaksi terhadap problem dan kondisi masyarakat. Sebagaimana dipaparkan dalam pembahasan terdahulu, relasi umat Islam dengan non Muslim menunjukkan dinamika tertentu, adakalanya dalam kedaan harmonis-akomodatif dan pada saat lain mengalami disharmonis- 
konfrontatif. Kedua kategori di atas mencerminkan konteks kemunculannya secara historis sosiologis. Diduga, hadis-hadis yang bersifat apresiatif-akomodatif lahir dalam kondisi relasi sosial yang harmonis, sementara hadis-hadis yang bersifat kritis- konfrontatif lahir dalam kondisi relasi sosial yang disharmonis.

Ketiga, hadis-hadis tentang relasi umat beragama harus dibaca dengan menggunakan pendekatan humanis-kontekstual. Pendekatan humanis dimaksudkan untuk memandang dan memperlakukan umat non muslim sebagai sesama manusia dengan segala hak yang melekat padanya. Sementara pendekatan kontekstual adalah melakukan pemahaman hadis dengan mempertimbangkan konteks yang mengitarinya. Pendekatan ini ditempuh dengan cara menempatkan hadis dalam konteks kesejarahan, sebagai sebuah teks yang bersifat spesifik dan mengambil nilai-nilai dasar dan prinsip-prinsip universal untuk diterapkan dalam konteks dan budaya yang berbeda. Dengan menggunakan dua pendekatan ini diharapkan hadis-hadis yang secara redaksional dianggap tidak relevan dengan konteks kekinian akan tetap bisa diamalkan. []

\section{DAFTAR PUSTAKA}

Abduh, Muhammad. Tafsir al-Qur'an al-Karim: Juz Amma, Kairo: Dar Maktabi al-Shab, 1991.

Abdullah, Ali Muhammad Salí. al-Hiwàr ad-Dinīy al-Ibrāhimìy fi Mizàn al-Qứàn. Kairo: Dar as-Salam, 2007.

Anshari, Endang Saefudin. Ilmu, Filsafat dan Agama. Surabaya: Bina Ilmu, 1991.

Bāqī, M. Fuad Abd Al-. Al-Mu'jam al-Mufahrs li Alfäz al-Hādìs anNabawi. Leiden: E.J. Brill, 1962

Bāyūmī, Abd al-Mu'țī Muḥammad, Al-Islām fì al-Qarn al-Hādi wa al'Isyrin Ru'yah 'Asriyyah li al-Isläm. Mesir: Nahụah Mișr, 2010.

Bukhārī, Al-Imām Ab̄̄ Abdillah Muḥammad bin Ismā'il bin Ibrāhīm bin Al-Mugīrah bin Bardizbah, Al-Jämi al- Sahịh Al-

Bukhārì, Jilid 1, Juz 1, Dār al-Fikr, Beirut-Libanon, 2000.

CD Mausu'ah al-Hadis asy-Syarif al-Kutub at-Tis'ah. 
End, Van den .\& Christiaan de Jonge, Sejarah Perjumpaan Gereja dan Islam, Jakarta: Sekolah Tinggi Teologi, 2001.

Galib, Muhammad M, Abl al-Kitab Makna dan Cakupannya. Jakarta: Paramadina, 1998.

Ghazali, Adeng Muchtar. Agama dan Keberagamaan dalam Konteks Perbandingan Agama, Bandung: Pustaka Setia, 2004.

Hisyām, Ibn, al-Sìrah an-Nabawiyah. Beirūt: Dār Iḥyā' wa at- Turāì al- 'Arabīy. 1997, juz 1.

Hitti, Philip K. The Origin of the Islamic State, New Cork: Columbia University, 1916. vol. 1.

Ibn Kà̄īr, al-Bidāyah wa an-Nihāyah. Kairo: Dār al- Hadī̇s, 1992. juz IV

-------, Tafsìr al- Qur'ān al- 'Azìm. Dār al- 'Ihyā' al- Kutub al'Arabiyyah, [t.th], vol.2.

Khāliq, Farīd Abdul. Fì al-Fiqh al-Islāmi: Mabādi’ Dustūriyyāt. Mesir: Dār asy-Syurūq, 1968.

Mugni, Syafiq A. "masyarakat Pra Islam" dalam Taufik Abdullah (ed), Ensiklopedi Tematis Dunia Islam. Jakarta: Ichtiar baru Van Houve, 2002.

Muhajir, Noeng. Filsafat Ilmu: Telaah Sistematis Fungsional Komparatif . Yogyakarta: Rake Sarasin, 1999.

Naisābūrī, Abū al- Husaīn bin al-Hajijāj bin Muslim al-, Sạhḥh Muslim, Jilid 4, Juz 7. Beirūt Dār al-Fikr, [tt].

Nasution, Adnan Buyung. "Hak Asasi Manusia dalam Masyarakat Islam dan Barat" dalam Natsir Tamara dan Elza Peldi Taher (ed), Agama dan Dialog Antar Peradaban. Jakarta: Paramadina, 1996.

Noorhidayati, Salamah. Hadis-hadis Diskriminatif terhadap Umat Beragama Lain. Tulungagung: STAIN Press, 2010.

Rachman, Budhy Munawar, dkk, Islam Pluralis: Wacana Kesetaraan Kaum Beriman. Jakarta: Paramadina, 2001.

Raḥmān, Abd ar-Raḥmān Muḥammad Abd al-, Uslūb al-Qur'ān alKarìm fì Da'wah Abl al-Kitāb, Mesir: Dār al-Yaqīn, 2009.

Rahman, Fazlur. Islam dan Modernitas, terj. Aksin Muhammad. Bandung: Pustaka, 1985.

Rị̣ā, M. Rasyīd. Tafsìr al-Manār . Beirut: Dār al-Ma'rifah, 1994.

Sa’ad, Ibn, Ṭabaqāt al-Kubrā. Beirūt: Dār Șādir, 1960/1380. vol 1. 
Sachedina, Abdul Aziz. Kesetaraan Kaum Berima. Jakarta: Serambi, 2002.

Shihab, M. Quraish. Tafsir al-Mishbah. Jakarta: Lentera Hati, 2003.

Țabarī, Muhammad Ibn Jarīr al-. Tärïkh ar-Rusul wa al-Mulük, Kairo: Dār al-Ma’ārif, 1960. vol 1.

Tim Penyusun, Kamus Besar Bahasa Indonesia. Jakarta: Departemen Pendidikan dan Kebudayaan Bekerjasama dengan Balai Pustaka, 1994. edisi 2.

Wehr, Hans. A Dictionary of Modern Written Arabic (ed) J. Milton Cowan Wiesbaden, London: Otto Harrassowittz, 1971.

\section{Jurnal:}

Sabjan, M. Azizan dan Akhir Sakhirah M. "Konsep Ahl al-Kitab dalam Tradisi Islam", dalam Islamia, Tahun I No. 4 JanuariMaret 2005. 